Fea, N. and S. Hartley 2018. The balancing act of nest survival: survival of a small endemic bird in the face of ship rat predation and other risk factors. Avian Conservation and Ecology 13(2):11. https://doi.org/10.5751/ACE-01284-130211

Copyright (C) 2018 by the author(s). Published here under license by the Resilience Alliance.

Research Paper

\title{
The balancing act of nest survival: survival of a small endemic bird in the face of ship rat predation and other risk factors
}

\author{
Nyree Fea ${ }^{1}$ and Stephen Hartley ${ }^{1}$ \\ ${ }^{1}$ Centre for Biodiversity and Restoration Ecology, School of Biological Sciences, Victoria University of Wellington
}

\begin{abstract}
Predation of indigenous birds by ship rats (Rattus rattus, [Muridae]) is an international conservation crisis and has been implicated in the decline of many endemic species. Effective management of threatened ecosystems relies on accurate assessments of invasive species impacts on native wildlife. To quantify the link between ship rat abundance and survival of small, endemic birds we investigated the prevalence of rat predation on nesting New Zealand Fantails (Rhipidura fuliginosa placabilis, [Rhipiduridae]), and its importance relative to other risk factors such as nest microsite. We surveyed 106 nests across forested reserves in Wellington City, New Zealand. Local abundance of ship rats was indexed using chew-cards placed around the nest and with tracking tunnels throughout reserves. We modeled the effects of ship rat abundance, weather, observer impact, and attributes of the nest for their influence on nest survival. Fantails were more likely to abandon nests located higher in trees and those built earlier in the breeding season. More nests failed when rat abundance was higher. Where ship rat abundance reached a $25 \%$ chew-card index (CCI), the probability of the nest surviving dropped below $50 \%$, and for CCI above $45 \%$ only $20 \%$ of nests were predicted to survive. However, Fantails also exhibited a resilient strategy that improved survival because nests located on thinner branches were less likely to suffer predation. Our research suggests that nesting strategies of Fantails involve trade-offs and strategies that might protect them against one threat, might expose them to others. Fantails are a common endemic species and cope with moderate levels of nest predation, however conservation of small endemic birds with less resilient breeding strategies is likely to require management of ship rat populations to low levels.
\end{abstract}

\section{L'art du compromis de la survie du nid : la survie d'un petit oiseau endémique face à la prédation par le rat noir et d'autres facteurs de risque}

RÉSUMÉ. Enjeu de conservation d'ampleur internationale, la prédation d'oiseaux indigènes par le rat noir (Rattus rattus, [Muridae]) est associée à la diminution de nombreuses espèces endémiques. Le succès de la gestion d'écosystèmes menacés dépend de l'évaluation précise des impacts d'espèces envahissantes sur la faune indigène. Pour quantifier la relation entre l'abondance de rats noirs et la survie de petits oiseaux endémiques, nous avons examiné la fréquence de prédation du Rhipidure à collier (Rhipidura fuliginosa placabilis, [Rhipiduridae]) nicheur par le rat, et son importance relative par rapport aux autres facteurs de risque tels que le microsite du nid. Nous avons suivi 106 nids dans des réserves boisées dans la ville de Wellington, en Nouvelle-Zélande. L'abondance locale des rats noirs a été évaluée au moyen de cartes à morsures placées autour des nids et de tunnels de suivi dans les réserves. Nous avons modélisé l'effet de l'abondance du rat noir, des conditions météorologiques, de l'impact de l'observateur et des attributs du nid pour déterminer leur influence sur la survie du nid. Les Rhipidures à collier avaient tendance à abandonner leur nid quand celui-ci était placé haut dans un arbre ou avait été construit tôt en saison. L'échec des nids était constaté plus souvent quand l'abondance des rats était élevée. Là où l'abondance de rats noirs atteignait un indice de $25 \%$ fondé sur les cartes à morsures (ICM), la probabilité de survie du nid dégringolait sous $50 \%$, et pour un ICM au-dessus de $45 \%$, le modèle prédisait seulement $20 \%$ de survie des nids. Toutefois, les rhipidures ont aussi adopté une stratégie de résilience qui amélioraient la survie, parce que les nids placés sur des branches plus fines étaient moins susceptibles de subir de la prédation. Notre recherche indique que les stratégies de nidification des rhipidures comportent des compromis, et qu'une stratégie qui les protège d'une menace les expose peut-être à d'autres. Le rhipidure est une espèce endémique commune qui fait face à un degré de prédation des nids moyen; cependant, dans le cas de la conservation de petits oiseaux endémiques moins résilients dans leurs stratégies de nidification, les gestionnaires doivent vraisemblablement maintenir les populations de rats noirs à de bas niveaux.

Key Words: density impact function; fantail; introduced mammals; predation; Rattus

\section{INTRODUCTION}

Predation of indigenous birds by introduced, invasive mammals is an internationally common and widespread problem (Courchamp et al. 2003, Towns et al. 2006, Doherty et al. 2016). Waves of avifaunal extinctions have repeatedly occurred on oceanic islands after the arrival of humans and the introduction of mammalian predators (Atkinson 1985, Blackburn et al. 2004) because the bird populations are often limited in size and range and they are particularly vulnerable to habitat loss and predation by novel species (Johnson and Stattersfield 1990). Predation by invasive mammals has been implicated in the decline of many species of birds across the Pacific region (Robertson et al. 1994, 
Vanderwerf and Smith 2002, Innes et al. 2010a, Shiels et al. 2014, Doherty et al. 2016) with the loss of $50 \%$ of all breeding bird species in New Zealand after the arrival of humans and the introduction of mammalian predators and competitors (Holdaway et al. 2001). The well-documented negative effects of ship rats (Rattus rattus) on island birds has led conservation managers across the Pacific to focus on reducing rat populations in forests of high conservation value (Robertson et al. 1994, Innes et al. 1999, Vanderwerf and Smith 2002, Gillies et al. 2003). However, conservation projects across New Zealand have reported full recovery of ship rat populations one to two years after control has ceased (Innes et al. 1995, Sweetapple and Nugent 2007, Ruscoe et al. 2011, Griffiths and Barron 2016). Outside of intensively managed areas, continual suppression of ship rat populations is rarely achieved, and their persistence is of concern for bird species susceptible to ship rat predation.

In a climate of constrained budgets, it is important to know the relationship between management actions and conservation outcomes such as breeding success or population recovery of threatened species. Because management often has the proximal aim of reducing the densities of pest species (Duron et al. 2017), the ability to relate pest abundance to likely conservation outcomes allows for more accurate cost-benefit analysis and prioritization of resources. Such relationships when quantified are known as ecological "density impact functions" (Norbury et al. 2015).

Predation of birds by ship rats causes population decline for many native bird species in New Zealand (Innes et al. 2010a). Nest survival has been studied following control of invasive mammals, with results suggesting the positive effects of control are nullified with the rapid recovery of ship rat populations (Armstrong et al. 2006). These authors modeled survival parameters for the North Island Robin (Petroica longipes), a medium-sized endemic passerine (35 g average female body weight; Heather et al. 2015), according to a range of ship rat abundance indices. Armstrong et al. (2006) described a significant linear relationship characterized by moderate nesting success when ship rat abundance was low ( $\leq$ $5 \%$ ) and extremely low nesting success at high ship rat abundance. Because body size of prey relative to a predator is an important factor influencing prey vulnerability (Cohen et al. 1993, Newton 1998 ) it would be useful to also quantify the relationship between ship rat abundance and nest survival of small endemic birds $(<$ $20 \mathrm{~g}$ adult mass). However, obtaining sufficiently large samples of nest attempts by threatened bird species is likely to be limited by the very nature of the subject's rarity. Additionally, disrupting the nesting attempts of rare species can have dire consequences. Calculation of density impact functions for predation impacts on common surrogate species provides an ethical approach with a higher likelihood of sampling success, one that could be applied as best-case scenarios for conservation managers for predicting survival of threatened endemic species.

In addition to avoiding predation, nest survival and successful fledging of chicks is also dependent on favorable abiotic factors throughout the nesting period. Severe weather, e.g., extreme temperatures, wind, or rainfall, can not only undermine the structure of the nest and threaten nest young, but can also limit the behavior of nesting adults through the energy-demanding breeding season (Conrey et al. 2016). Human activity at a nest potentially introduces further factors that may alter survival (Richardson et al. 2009), therefore research should account for weather and human effects alongside predation threats to understand the relative importance of risk factors.

Nest height and concealment are often investigated in studies assessing the influence of nest placement on nest predation, and how this relates to the type of predator, whether it is an avian, arboreal, or ground predator (Colombelli-Négrel and Kleindorfer 2009). In a study of a small passerine (the Blackcap, Sylvia atricapilla), Remeš (2005) showed that nest height affected survival differently depending on whether the predators were avian or rodents (mice and voles). Lower nests survived better with respect to avian predation but worse against rodent predation. They also found less avian predation on more concealed nests with no effect of concealment on levels of rodent predation. Higher nests of the endemic Yellowhead (Mohoua ochrocephala) and Yellow-fronted Parakeet (Cyanoramphus auriceps) in the south of New Zealand were less likely to be preyed upon by stoats and ship rats (Elliott et al. 1996). In contrast to these studies, van Heezik et al. (2008) studied the influence of nest placement on survival of New Zealand Fantail (Rhipidura fuliginosa fuliginosa, South Island subspecies) nests and recorded increased nesting success for lower nests even though mammalian predators (rats and possums) were the main group of predators identified by tooth marks on artificial eggs. They concluded that the higher nests, which were also more concealed, fared worse because they were more exposed to the negative effects of inclement weather.

In New Zealand, agile mammals, with arboreal abilities, now pose the greatest threats to native birds. We therefore set out to investigate an additional nest placement factor, the diameter of the nest branch, a placement strategy that might limit the approach of a climbing predator. This aspect of nest site has received little attention in the literature, and we could find no examples where this has been investigated for species targeted by ship rats. Ship rats have been identified as major predators at fantail nests (Mudge 2002, van Heezik et al. 2008) and these very small birds might exhibit nesting adaptations that utilize the large differences in weights between predator (average weight of an adult ship rat in New Zealand, $146 \mathrm{~g}$; King 2005) and prey (8 g average female fantail body weight; Heather et al. 2015).

There is evidence that endemic bird species adapt nest placement or other nesting strategies to respond to novel predatory threats (Massaro et al. 2008, Vanderwerf 2012). Martin (1993) postulated that nest-site selection could be evolutionary conserved, with species in the same genus exhibiting similar nesting habits across the various regions in which they occur. This implies that although predatory mammals have not been present on New Zealand since it separated from Gondwana 80 million years ago (Worthy and Holdaway 2002), taxa that colonized more recently (such as the New Zealand Fantail) may exhibit antimammalian predatory responses that hark back to wider Australasian origins. Conversely, birds with high-level endemism in New Zealand, may be particularly vulnerable to novel, invasive mammalian predators (Blackburn et al. 2004).

To investigate factors that might influence nest survival of a small, endemic bird we measured the nesting success of the New Zealand Fantail (Rhipidura fuliginosa placabilis, North Island subspecies), 
across forest fragments in Wellington City. We chose to monitor fantails because they are one of New Zealand's smallest endemics birds and are known to be attacked on the nest by ship rats (Mudge 2002). Although endemic, the New Zealand Fantail is closely related to the Australian Grey Fantail (Nyári et al. 2009), and therefore shares a fairly recent evolutionary history with native, mammalian predators. Fantails are one of New Zealand's smallest birds and build small, light nests that could be placed beyond reach of the larger ship rat. They are also a common and widely distributed endemic species (Heather et al. 2015) and therefore might possess resilient nesting strategies.

Our primary objective was to quantify threats to a common endemic bird, including threats from the introduced ship rat. Nests in fragmented habitat, such as urban forest reserves, are vulnerable to ship rat predation because rats easily invade forests from other quality habitat (Stirnemann et al. 2015) and long-term suppression is therefore problematic (Innes et al. 2010b). The forested reserves of Wellington provided an accessible site where we were likely to encounter abundant ship rats and fantails. We aimed to (1) derive a density impact function between an index of rat abundance and an ecological outcome (nest survival of a small passerine); (2) investigate the effects of weather and observer presence on nest survival; and (3) determine the relative influence of tree-height, nest height, nest branch-width, and nest concealment on nest survival.

\section{METHODS}

\section{Sites and seasons}

We searched for nests in forested reserves in Wellington City, New Zealand $\left(41^{\circ} \mathrm{S}, 175^{\circ} \mathrm{E}\right.$; see Fig. A1.1 in Appendix 1, for a map of the study area). The reserves are remnant patches of native forest with hard edges bordered by urban areas and range in area from 2-50 hectares. The forests comprise broadleaf tree species with scattered native podocarps and exotic pine trees (Gabites 1993). We monitored nests between December 2014 and February 2015, across four reserves in Wellington and again between August 2015 and February 2016, for a second, complete breeding season throughout the city (20 reserves). In the second breeding season, we adjusted our search effort to locate equal numbers of nests across reserves with moderate, low, and zero rat abundance, with rat abundance based on the first season's tracking tunnels. Nests from this last group (zero rats) were located in Zealandia, a fenced eco-sanctuary in central Wellington from which introduced mammals, except mice, have been eliminated (Empson and Fastier 2013).

\section{Nest survival}

We located nests by following adult fantails exhibiting nesting behavior (collecting twigs from the ground or moss from trees, catching an insect and flying off with it in their beaks). Once a nest was sighted we ascertained its developmental stage by observing behavior of the parents or by nestling plumage and behavior (Amiot et al. 2015). We estimated the days for each phase after clutch initiation as 3-6 days for laying, 13-16 days for incubation, and 11-16 days with nestlings (Heather et al. 2015). We attached one or two cameras (Bushnell HD trail cameras) to trees or shrubs between 0.5 and 5.0 meters from the nest. No cameras were used if the nest was visible from a public track.
Camera placement was delayed until after egg-laying to minimize the risk of abandonment of early stage nests.

We visited nests approximately weekly to service cameras and to record the nesting behavior of adults. Nests were observed from a distance for up to 30 minutes. If there was no activity during that time, we checked the nest contents either visually or using a video camera mounted on an extendable tripod to determine nest outcome. The contents of high nests were checked from a vantage point with binoculars where possible. If the nest appeared concluded, i.e., no action on the nest by adults and no live young present, we then gathered evidence to determine the cause of the nest's outcome.

We categorized nests fully built but never receiving a clutch as abandoned. Nests were regarded as abandoned on the first day activity was observed to have ceased at the nest and where no eggs were apparently laid. If nests appeared to be deserted by the parents, and nest young were found dead in the nest, with no evidence of predation, we assigned these nests a deserted status. We used camera footage or other evidence of nest disturbance to determine if nests spilled due to heavy rain or strong winds. Nest predation was recorded if any one of the following criteria were fulfilled: (1) the nest was empty before chicks could possibly have fledged; (2) there was evidence of a predator, e.g., rat scat in the nest; (3) egg or chick remains were found in or near the nest; (4) camera evidence showed a predator at the nest site. Nest success was confirmed if all of the following criteria were fulfilled: (1) the nest was estimated to be at least 27 days postclutch initiation; (2) chick droppings were found under the nest; (3) there was no evidence of predator visitation from camera footage (if available). Because nest success is defined by the survival of any nest young to fledging (Mayfield 1975), we spent considerable effort attempting to sight (and count) fledglings within one week of the nest's conclusion to conclusively determine the nest's success.

We measured characteristics of the nest to investigate the relationship between nest placement and nest survival. We recorded the following nest attributes: tree height $(\mathrm{m})$, nest height $(\mathrm{m})$, nest branch diameter $(\mathrm{mm})$ at the point of attachment of the nest to the branch, and percent foliar cover $2 \mathrm{~m}$ above and $2 \mathrm{~m}$ below the nest using the foliage cover scale method commonly used for assessing canopy cover (Department of Conservation 2014).

\section{Rat relative abundance}

We estimated ship rat abundance within reserves using two indices of relative abundance. First, for both breeding seasons, we deployed transects of tracking tunnels in reserves where multiple nests, separated by $>100 \mathrm{~m}$, had been discovered at building stage. Tracking tunnel monitoring followed the protocols outlined by Gillies and Williams (2013) with randomly located lines of 10 tunnels with $50 \mathrm{~m}$ spacing and baited with peanut butter. However, as we were monitoring forest fragments, only 1-2 transects could be placed within each reserve. Tunnels were run for one fine night in February each year. Using the distinctive print impressions of rats, we calculated percent tracked tunnels for that transect and, where two transects were placed, we took the average. For two of the reserves (Otari-Wilton's and Johnsonville) we utilized tracking tunnel data collected by Greater Wellington regional council in February of both years as part of their routine monitoring. 
Tracking tunnels are widely used across New Zealand forests for estimations of relative abundance of rodents. Rat tracking rates can predict biologically plausible growth rates of rat populations (Elliott et al. 2018) and have been shown to reliably predict nest success for threatened bird species (Innes et al. 1999, Armstrong et al. 2006). For maximal correlation between rat abundance indices to be upheld, Blackwell et al. (2002) highlighted the importance of adhering to monitoring protocols such as those prescribed by Gillies and Williams (2013). Blackwell et al. (2002) also recommended that a second index of abundance be used alongside tracking tunnels. An additional estimate was particularly useful in our study, conducted within forest fragments, where we were limited to only 1-2 transects per reserve (rather than 4, the recommended minimum in Gillies and Williams 2013).

During the second breeding season, we employed an additional method to estimate the relative abundance of ship rats in the vicinity of the nest. We set out chew-cards around concluded nests (fledged or failed) to provide an estimate of abundance in the immediate vicinity of the nest. Chew-cards were made of corflute (Graley Plastics, Wellington), measured $90 \mathrm{~mm}$ x $180 \mathrm{~mm} \times 3.3$ $\mathrm{mm}$, with internal flutes that we baited with peanut butter. Chewcards were deployed around nests, that had received a clutch, in a $3 \times 3$ grid (min. $2 \times 3$ grid if access was limited on one border, i.e., $6-9$ cards) at $25 \mathrm{~m}$ spacing. To target the monitoring toward the ship rat, we placed chew-cards at $1.4 \mathrm{~m}$ height, directly above a tree-limb on trees with a diameter at $1.3 \mathrm{~m}$ height of $>25 \mathrm{~mm}$. Both ship rats and Norway rats (Rattus norvegicus) are present in Wellington City forests (personal observation) however Norway rats are reluctant climbers and therefore unlikely to prey upon fantail nests (Foster et al. 2011). Chew-cards were deployed around the concluded nest and were left in situ for one fine night, as is prescribed for tracking tunnel monitors (Gillies and Williams 2013). Using the distinctive bite marks of ship rats, we calculated percent chewed cards, i.e., the chew card index or CCI (Sweetapple and Nugent 2011).

\section{Analysis}

\section{Nest survival}

To estimate survival of fantail nests, we calculated expected daily survival rates (DSR) averaged across all nests that received eggs. Survival rates were calculated for nests by breeding season and separately for nests located across unfenced Wellington reserves and within the fenced sanctuary, Zealandia, where all mammalian predators, except mice (Mus musculus), have been removed. We calculated maximum likelihood estimates of DSRs, and variance over the entire nesting period, using the Nest Survival package (Rotella 2015) in program Mark v6.2 (White and Burnham 1999). The DSR is based on the Mayfield estimate (Mayfield 1975), which accounts for the number of days the nest was active (from clutch initiation) and the days the nest was not under observation. We calculated nesting success (the probability of a nest surviving from clutch initiation to fledged young) as the DSR raised to the power of 31 because this is the average number of days for the entire fantail nesting period (Heather et al. 2015).

We also explored time-dependent effects on the survival of nests that received eggs. Survival may vary throughout the season according to changes in abundance of predators or changes in the conspicuousness of the nest as the nest young mature. We explored these time dependent models in program Mark using (a) constant survival across the season; (b) a linear-time model with variation of nest-survival according to day of the season; (c) survival of nests at early, middle, and late stages of the season; (d) survival according to the nest phase (chick, nestling); and (e) survival according to the nest's age. We ranked these models in Mark using AICc. We then included the highest ranked time-dependent variable in the nest-site model ranking.

The assumptions of the nest survival model in program Mark are the following: (1) that nest fates are correctly determined; (2) that observer visits to the nest do not influence survival; (3) there is no significant heterogeneity of daily nest survival rates; and (4) that nest fates are independent (Dinsmore and Dinsmore 2007). Violation of assumption (1) is unlikely because we were able to make frequent nest checks, we employed intensive camera monitoring, and we were able to closely monitor breeding pairs to determine outcomes of nests. We also tested for the effects of observer presence to determine if violation of assumption (2) had occurred, as we modeled the effects of nest checks on nest abandonment and the effects of camera placement on nest predation. There is likely to be overdispersion in this data, however, as a result of violations of assumption (3) and (4). Currently there is no method to estimate extra-binomial variation in program Mark (Dinsmore and Dinsmore 2007). We were able to account for overdispersion in generalized linear mixed effect models (GLMMs) of nest abandonment and nest predation, with the addition of a random effect for fantail breeding pair. This accounted for the nonindependence of nest outcomes where multiple nests were recorded from a single breeding pair. Breeding pairs were identified as the two adults attending to the nest, or cluster of nests, which were all located within a $100-\mathrm{m}$ radius.

\section{Factors affecting nest abandonment}

To investigate possible causes of nest abandonment we ran a GLMM for all nests found at building stage with the binary fate of the nest (abandoned or clutch laid) as the response variable. We combined both 2014-2015 and 2015-2016 nests in this analysis because the average life span of a New Zealand Fantail is one year (Heather et al. 2015) and therefore pseudo-replication of nest survival data from a breeding pair across consecutive breeding seasons was unlikely. We also included a random effect variable for fantail breeding pairs identified each season. We specified a logit link function and binomial error structure. To test for the influence of weather covariates (minimum temperature $\left[{ }^{\circ} \mathrm{C}\right]$, total rainfall $[\mathrm{mm}]$, and maximum wind gusts $[\mathrm{m} / \mathrm{sec}]$ for the seven days prior to conclusion) we sourced climate data from a central Wellington weather station (Kelburn Station available at http://cliflo.niwa.co.nz). We also investigated the effects of season, using the day of the season the nest was observed abandoned or laid in (counted from 28 August, the earliest day of year that nesting was observed), plus year (2014-2015 or 20152016) and nest-placement, i.e., branch width and nest height. Finally, because we suspected that human visitation to the nest would also be likely to cause disruption, we included a continuous effect for the number of visits to the nest (before nest abandonment/laying) for all nests found at building stage. To exercise caution and minimize human presence at early stage nests, we did not estimate rat abundance at nests unless they had received a clutch and the nest attempt had been concluded. 
We analyzed the influence of these factors on abandonment using all factors in an additive, global GLMM in the multimodel inference R-package MumIn, version 1.15.6 (Barton 2016). We then ranked models representing all possible combinations of factors (128 models total) using Akaike's Information Criterion for model selection, adjusted for small sample sizes (AICc; Burnham and Anderson 2002). The Akaike weights of all models in the set summed to one and the model with the highest weight was accepted as most closely representing reality, i.e., the best fit to the data at hand. Models were ranked by measuring the change in AICc from the best model. Models with a change of $<2$ from the best model have substantial empirical support, models with a change of 4-7 have considerably less support, and models with a change of $>10$ have essentially no support (Burnham and Anderson 2002). To describe the relative importance of each factor we calculated the sum of the Akaike weights, the betaestimate, and the beta standard error (SE) across all the models in which it was present, i.e., 64 models each. Variables whose mean beta is more than twice the magnitude of SE may be considered significant from a hypothesis-testing perspective, even in the face of uncertainty around model specification (Payton et al. 2003).

\section{Rat density impact function}

To estimate the relationship between rat abundance and nest survival, we modelled nest survival in another GLMM as a function of ship rat abundance, once using data from tracking tunnels and a second time using chew-cards as our index of rat abundance. Nests that were abandoned, spilled, or preyed upon by birds were excluded from this calculation of a density impact function. All other nests were included regardless of stage discovered because the nest's outcome in relation to the abundance of ship rats was the relationship under investigation. Following the methods outlined by Dinsmore and Dinsmore (2007) we assumed that nest fates were correctly determined. We analyzed the data in the lme4 R-package (Bates et al. 2015) with a binary response variable (survived or failed) and rat abundance as the explanatory variable. We included a random effect in the model for the fantail breeding pair, and we specified a logit link function and binomial error structure.

\section{The effects of nest-site on nest predation}

To estimate effects of nest placement on nest predation we analyzed successful nests and those that failed to rat predation and unknown predation using full model averaging of each nestsite attribute, i.e., five variables, represented in 16 models each, in program Mark. Nests that were abandoned, spilled, or preyed upon by birds were excluded from this analysis. The nest-site attributes were branch width, rodent abundance (using the nestsite estimate from chew-cards), nest height, cover above, and cover below. We included the highest-ranking time-dependent variable in these models. We also tested for a possible effect of reduced predation on nests with cameras using the one-sided binomial test in the $\mathrm{R}$ base package, excluding nests that were spilled, abandoned, or located in Zealandia.

\section{Multicollinearity}

We checked for multicollinearity between explanatory variables using Spearman rank correlation tests in the $\mathrm{R}$ base package. If a pair of variables had a correlation coefficient $\left(r_{\mathrm{s}}\right) \geq 0.7$ we excluded from analysis the variable shown less in the literature to be relevant to nest survival. We used the Spearman rank correlation coefficient, rather than the Pearson correlation coefficient, because the former makes no assumptions about linearity in the relationship between the two variables. The variables nest height and tree height were strongly correlated $(r=$ 0.87 ) as nests were generally located directly under the tree's canopy, i.e., average cover above the nest was $81.8 \%$ whereas below it was $24.3 \%$. Tree height was therefore omitted from analyses.

\section{RESULTS}

We monitored 106 fantail nesting attempts, 67 of these were discovered at the nest-building phase, 16 at incubation stage and 23 with nestlings already present in the nest. Nests were located in 22 different tree species, especially kawakawa (Piper excelsum, 22 nests), mahoe (Melicytus ramiflorus, 16 nests), and karaka trees (Corynocarpus laevigatus, 15 nests). A total of 68 breeding pairs fledged on average of 1.3 chicks per nesting attempt; the average number of clutches per breeding pair per season was 1.6, with a maximum of four clutches in a season identified for one pair. Sixtyseven nests were monitored with cameras.

Over the complete breeding season (2015-2016), fantail nesting success in unfenced urban reserves was $44.5 \%$ (CI 95\% $=30.0$ 58.2). For both seasons, rats were responsible for most fantail nest predations outside Zealandia (14 / 26 predations) with ship rats the only invasive mammal observed on camera. The structure and lining of the concluded nest appeared undisturbed for all predation-unknown nests, and 6 of the 14 predation-rat nests, i.e., "Clean" (sensu Brown et al. 1998). Although no direct observation of predation upon adult fantails was made, an adult went missing from the breeding pair after 12 of 23 nest predation events. Three avian predation events were recorded: two by the introduced Blackbird (Turdus merula) and one by the native owl (Ninox novaeseelandiae). Outcomes are shown for all nests in Table 1 and in Fig. A1.2 in Appendix 1. Estimates of rat abundance (from chewcards and tracking tunnels) and nesting outcomes per site are available in Table A1.1 in Appendix 1.

Table 1. Classification of nesting outcomes for New Zealand Fantail (Rhipidura fuliginosa placabilis, North Island subspecies) nests monitored from 2014-2016 across Wellington City forested reserves. Zealandia is a fenced reserve from which rats, mustelids, and possums have been completely removed.

\begin{tabular}{lccc}
\hline \hline & $2014-2015$ & \multicolumn{2}{c}{ 2015-2016 } \\
\cline { 2 - 4 } Number & Wellington & Wellington & Zealandia \\
\hline Nests Commenced & 25 & 65 & 16 \\
Abandoned & 1 & 13 & 2 \\
Deserted & 0 & 4 & 0 \\
Spilled & 1 & 1 & 1 \\
Predation-Rat & 2 & 12 & 0 \\
Predation-Bird & 1 & 0 & 2 \\
Predation-Unknown & 3 & 8 & 1 \\
Successful & 17 & 27 & 10 \\
Daily survival rates & 0.983 & 0.974 & 0.987 \\
Nesting success ${ }^{\dagger}$ (CI 95\%) & $58.0(30-78)$ & $44.5(30-58)$ & $66.4(34-86)$ \\
\hline${ }^{\dagger}$ Nesting success $=$ daily survival rate ${ }^{\wedge}$ 31 (31 days is the average nesting \\
period for the NZ Fantail). This estimate can be calculated only for nests \\
that received a clutch.
\end{tabular}


Table 2. Multimodel assessment of the influence of nest placement, season, and weather variables on nest abandonment $(\mathrm{n}=67$, where $\triangle \mathrm{AICc}<4$, i.e., 28 of 128 models presented). All models include a constant intercept term and a random term for New Zealand Fantail (Rhipidura fuliginosa placabilis, North Island subspecies) breeding pair. Summed model weights and averaged beta estimates (plus error) are calculated from the full model set.

\begin{tabular}{|c|c|c|c|c|c|c|c|c|c|c|c|}
\hline $\begin{array}{l}\text { nest } \\
\text { height } \\
\text { (m) }\end{array}$ & $\begin{array}{c}\text { season } \\
\text { day }\end{array}$ & $\begin{array}{c}\text { checks/ } \\
\text { day }\end{array}$ & $\begin{array}{c}\min . \\
\text { temp } \\
\left({ }^{\circ} \mathrm{C}\right)\end{array}$ & $\begin{array}{l}\max . \\
\text { wind } \\
(\mathrm{m} / \mathrm{s})\end{array}$ & $\begin{array}{l}\text { total } \\
\text { rain } \\
(\mathrm{mm})\end{array}$ & year & $\begin{array}{c}\text { branch } \\
\text { width } \\
(\mathrm{mm})\end{array}$ & $\mathrm{K}^{\dagger}$ & $\log \mathrm{Lik}^{*}$ & $\begin{array}{c}\Delta^{\S} \\
\mathrm{AICc}\end{array}$ & $\mathrm{W}_{\mathrm{i}}^{\mathrm{l}}$ \\
\hline$X$ & $\mathrm{X}$ & & & & & & & 4 & -31.18 & 0.00 & 0.12 \\
\hline$X$ & & & & & & & & 3 & -32.43 & 0.23 & 0.10 \\
\hline$X$ & $X$ & $\mathrm{X}$ & & & & & & 5 & -30.71 & 1.39 & 0.06 \\
\hline$X$ & $X$ & & $X$ & & & & & 5 & -30.83 & 1.63 & 0.05 \\
\hline$X$ & $X$ & & & & $X$ & & & 5 & -30.95 & 1.88 & 0.05 \\
\hline $\mathrm{X}$ & & & & $X$ & & & & 4 & -32.19 & 2.01 & 0.04 \\
\hline$X$ & & $X$ & & & & & & 4 & -32.19 & 2.02 & 0.04 \\
\hline$X$ & $X$ & & & $X$ & & & & 5 & -31.03 & 2.03 & 0.04 \\
\hline$X$ & & & $X$ & & & & & 4 & -32.22 & 2.08 & 0.04 \\
\hline$X$ & & & & & & $X$ & & 4 & -32.23 & 2.09 & 0.04 \\
\hline$X$ & $X$ & & & & & & $X$ & 5 & -31.08 & 2.14 & 0.04 \\
\hline$X$ & $X$ & & & & & $X$ & & 5 & -31.17 & 2.32 & 0.04 \\
\hline$X$ & & & & & & & $\mathrm{X}$ & 4 & -32.40 & 2.44 & 0.03 \\
\hline$X$ & & & & & $\mathrm{X}$ & & & 4 & -32.43 & 2.49 & 0.03 \\
\hline$X$ & $X$ & $X$ & & $\mathrm{X}$ & & & & 6 & -30.39 & 3.17 & 0.02 \\
\hline $\mathrm{X}$ & $X$ & & & $\mathrm{X}$ & $X$ & & & 6 & -30.49 & 3.37 & 0.02 \\
\hline$X$ & & $X$ & $X$ & & & & & 5 & -31.72 & 3.41 & 0.02 \\
\hline$X$ & $X$ & $X$ & & & $\mathrm{X}$ & & & 6 & -30.54 & 3.47 & 0.02 \\
\hline$X$ & $X$ & $X$ & $X$ & & & & & 6 & -30.57 & 3.53 & 0.02 \\
\hline$X$ & & $\mathrm{X}$ & & & & $X$ & & 5 & -31.79 & 3.55 & 0.02 \\
\hline$X$ & $X$ & & $\mathrm{X}$ & & $X$ & & & 6 & -30.59 & 3.57 & 0.02 \\
\hline$X$ & & $X$ & & $X$ & & & & 5 & -31.83 & 3.63 & 0.02 \\
\hline$X$ & $X$ & $X$ & & & & & $X$ & 6 & -30.65 & 3.69 & 0.02 \\
\hline$X$ & $X$ & & $X$ & & & & $\mathrm{X}$ & 6 & -30.68 & 3.76 & 0.02 \\
\hline $\mathrm{X}$ & $\mathrm{X}$ & & $\mathrm{X}$ & $\mathrm{X}$ & & & & 6 & -30.69 & 3.78 & 0.02 \\
\hline $\mathrm{X}$ & $\mathrm{X}$ & $\mathrm{X}$ & & & & $\mathrm{X}$ & & 6 & -30.70 & 3.79 & 0.02 \\
\hline $\mathrm{X}$ & & & $\mathrm{X}$ & $\mathrm{X}$ & & & & 5 & -32.00 & 3.97 & 0.02 \\
\hline $\mathrm{X}$ & $\mathrm{X}$ & & $\mathrm{X}$ & & & $\mathrm{X}$ & & 6 & -30.80 & 3.99 & 0.02 \\
\hline 0.94 & 0.55 & 0.31 & 0.29 & 0.28 & 0.27 & 0.25 & 0.24 & \multicolumn{4}{|c|}{$=$ summed model weights } \\
\hline 0.35 & -0.02 & 1.51 & 0.05 & 0.04 & 0.01 & 0.36 & -0.05 & \multicolumn{4}{|c|}{$=$ averaged $\beta$ estimate $^{\pi}$} \\
\hline 0.14 & 0.01 & 1.72 & 0.26 & 0.07 & 0.02 & 1.42 & 0.18 & \multicolumn{4}{|c|}{$=$ averaged $\beta$ standard error } \\
\hline $1.42^{\#}$ & 0.99 & 4.53 & 1.05 & 1.04 & 1.01 & 1.43 & 0.95 & \multicolumn{4}{|c|}{$=$ odds ratio $(\exp (\beta))$} \\
\hline
\end{tabular}

†number of parameters;

the maximized log-likelihood function;

$\S$ difference in AICc value for model relative to the top model;

the AICc weight for each model in the set of candidate models;

the effect of a unit increase in the parameter value, upon relative probability of abandonment;

${ }^{\#} 95 \%$ CI of the odds ratio does not include 1.

The model that assumed constant survival across the season fitted the data best for all time-dependent models (Table A1.2 in Appendix 1). The DSR was lower for nests with chicks than those with eggs, however a likelihood ratio test showed that this was not statistically significant ( $\chi 2=0.426, \mathrm{df}_{1}, P=0.514$ ). We therefore fitted a constant intercept term for all survival analyzed in program Mark.

\section{Factors affecting nest abandonment}

Nest height (mean 3.25, SE 0.30, range 1.2-15 m) was the most influential parameter for predicting nest abandonment $\left(Z_{65}=\right.$ 2.38, $P=0.017$; Table 2) with abandonment of 4 out of 5 nests located above 7 meters. Date was also present in the top model as nest abandonment occurred less often as the breeding season advanced and no nests were abandoned after 1 January (Fig. A1.2,
Appendix 1). Summed weights for each variable (from full model averaging) were nest height 0.94 , date 0.57 , nest checks per day 0.32 , minimum temperature 0.30 , total rain 0.29 , branch width 0.28 , and maximum wind gust 0.25 .

\section{Rat density impact function}

The likelihood of nest failure apparently increased as the chewcard index for rat abundance increased (mean $=6.36, \mathrm{SE}=1.79$, range $0-66.7$ ) although this trend was not significant (Fig. 1; as calculated from the full model set: $Z_{54}=1.71, P=0.087$ ). Once the chew-card index $(\mathrm{CCI})$ reached $25 \%$, the probability of a nest failing due to predation exceeded $50 \%$. At $45 \%$ CCI the expected probability of nest predation approached $80 \%$, however only two nests were monitored at sites with rat abundance above $40 \%$ CCI. 
Table 3. Multimodel assessment of the influence of nest placement and rat abundance on the daily nest survival of a New Zealand Fantail (Rhipidura fuliginosa placabilis, North Island subspecies) nest as calculated in program Mark $(\mathrm{n}=61$, where $\Delta$ AICc $<4$, i.e., 10 of 32 models presented). All models include a constant intercept term. Summed model weights and averaged beta estimates (plus error) are calculated from the full model set.

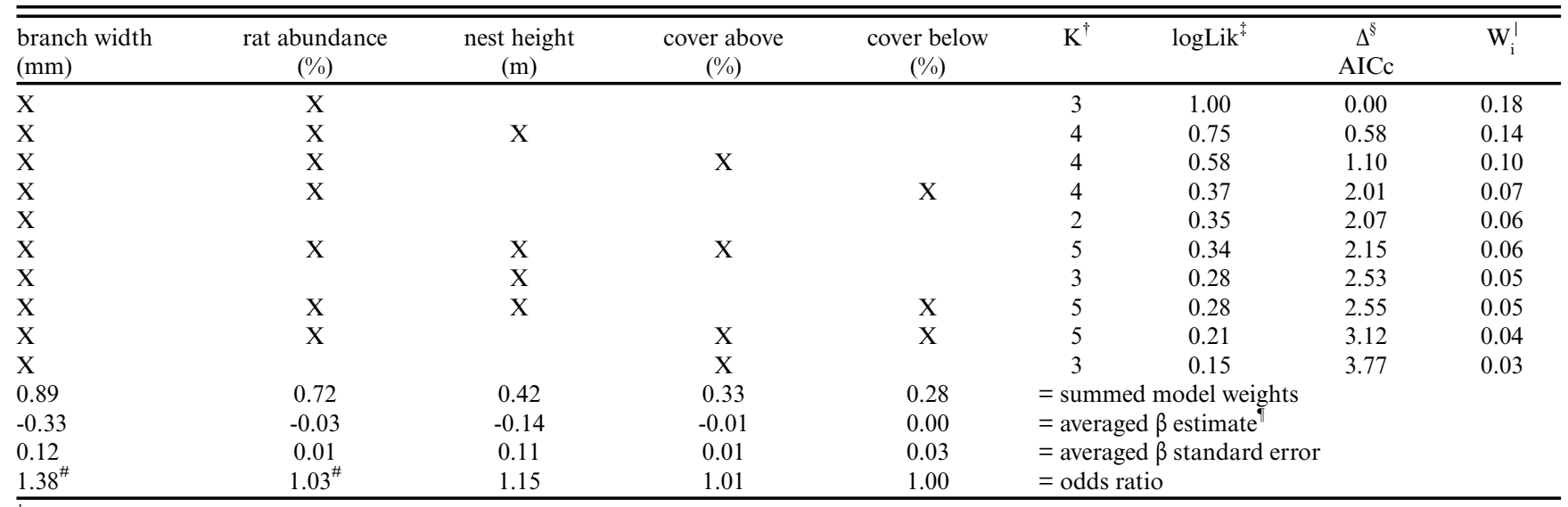

number of parameters;

the maximized log-likelihood function;

$\$$ difference in AICc value for parameter relative to the top parameter;

the AICc weight for each model in the set of candidate models;

"the effect of a unit increase in the parameter value, upon relative probability of predation;

${ }^{\#} 95 \%$ CI of the odds ratio does not include 1.

Fig. 1. Density impact function relating the observed abundance of ship rats (Rattus rattus) to the expected failure rate of New Zealand Fantail (Rhipidura fuliginosa placabilis, North Island subspecies) nests due to mammalian predation. The curved line represents the predicted probability of nest failure (right-hand y-axis) for a given index of rat abundance. This analysis excludes nests that were abandoned, or failed due to desertion, bad weather, or bird predation $(n=57)$. This analysis also excludes a single nest that failed to an unknown predator in Zealandia (where all mammals, except mice, are excluded). Fates of individual nests (circles) incorporate a random component (i.e., the binary outcome was "jittered") along the axis of rat abundance to reduce overlap and to illustrate sample sizes more clearly.

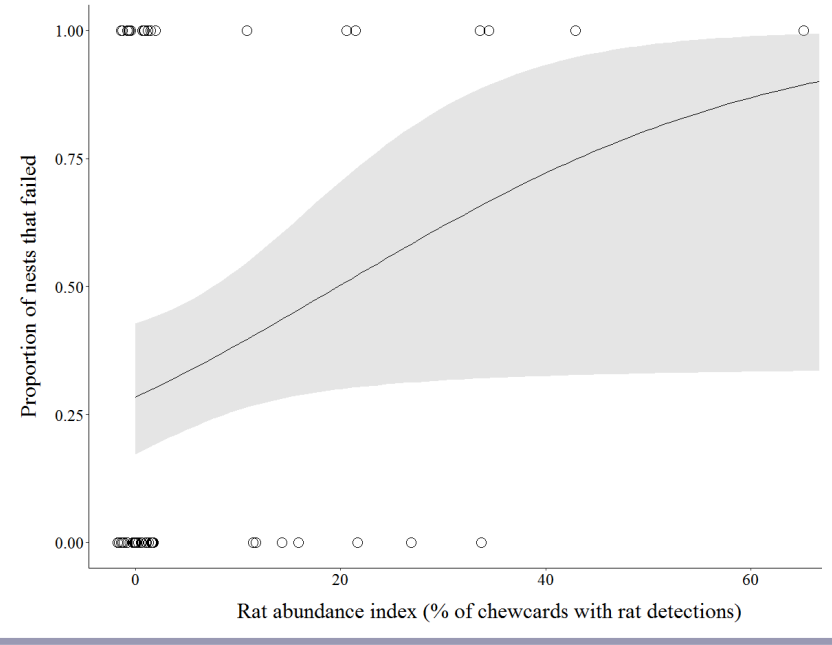

\section{The effects of nest-site on nest survival from predation}

Branch width and rat abundance were the most highly weighted variables in the multimodel analysis of predation followed by nest height, cover above, and cover below (Table 3). Nests on thin branches had significantly higher daily survival rates than nests on thicker branches across a wide range of rat abundance (Fig. 2). The average width of nest branches in this study was $8 \mathrm{~mm}$ (IQR $=8-10 \mathrm{~mm}$ ).

Fig. 2. Predicted daily survival rates of New Zealand Fantail (Rhipidura fuliginosa placabilis, North Island subspecies) nests, modeled according to varying rat abundance (x-axis) for nests located on branches of two different widths: dashed line $=6$ $\mathrm{mm}$ diameter (the minimum observed) and dotted line $=15 \mathrm{~mm}$ (the maximum observed). Relationships shown are mean $\pm 95 \%$ confidence interval (line \pm shaded band).

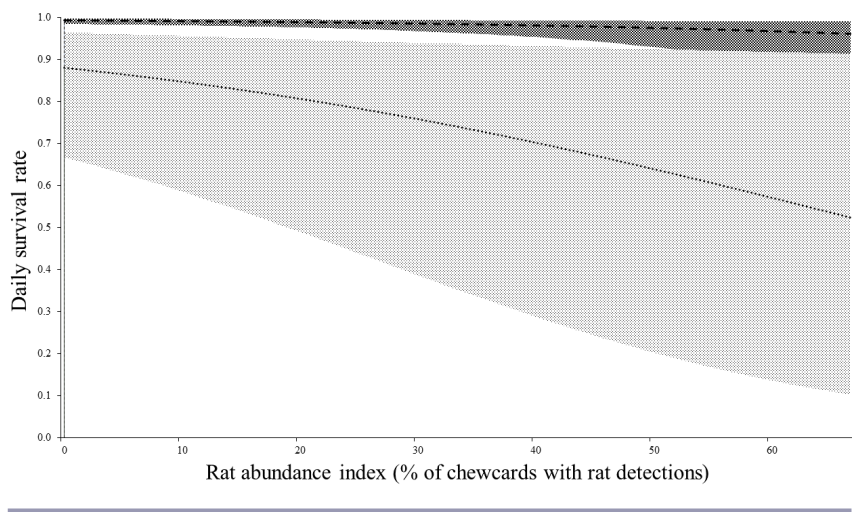


The presence of cameras did not significantly alter predation of nests with the proportion of successful nests with cameras (33 / 56) no greater than for nests without cameras (11/18; binomial test: $P=0.68$ ). In Figure 3, we provide an illustration of the proportions of nesting outcomes for the 2015-2016 breeding season, plus key findings from this study.

Fig. 3. Diagram showing proportional fates for $81 \mathrm{New}$ Zealand Fantail (Rhipidura fuliginosa placabilis, North Island subspecies) nesting attempts across forested reserves in Wellington City, 2015-2016. Bullet points state the key findings from the study. Illustration by David Young.

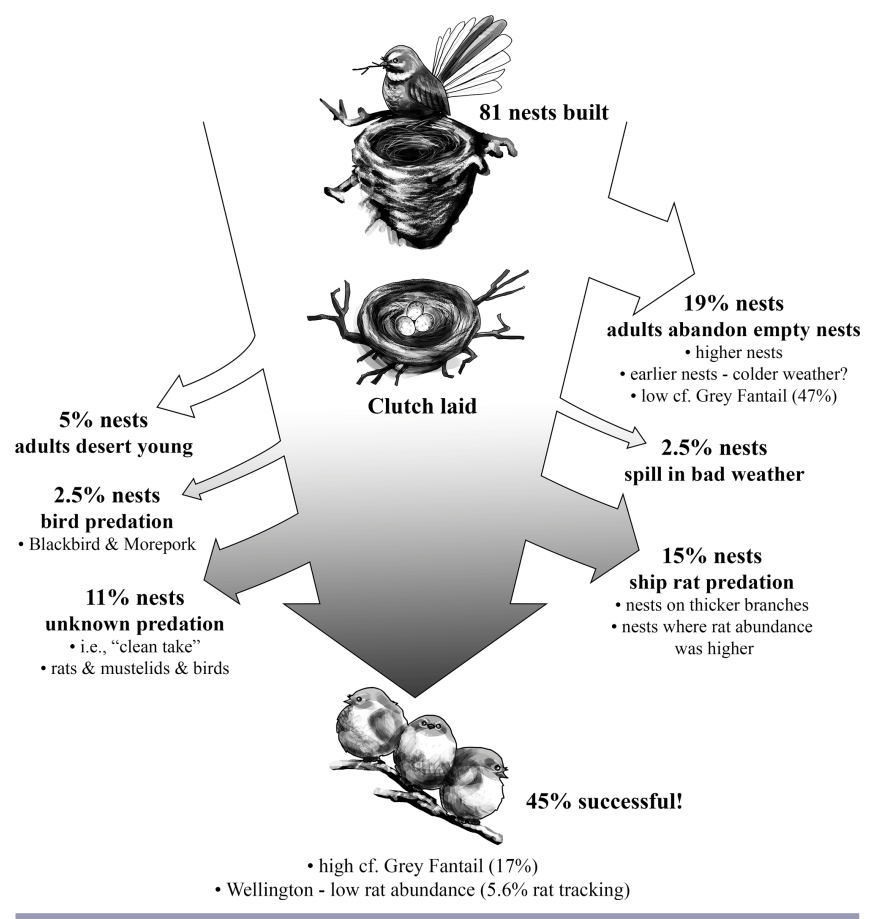

\section{DISCUSSION}

\section{Factors affecting nest abandonment}

Nests built higher in the canopy and in the earlier weeks of the breeding season had a greater probability of being abandoned, which suggests abandonment may be triggered by exposure to inclement weather. Higher rates of nest abandonment in the earlier weeks of the breeding season were also reported by Maddox and Weatherhead (2006) for the Common Grackle (Quiscalus quiscula). We were unable to link nest abandonment to particular weather events, however we sourced our climate data from a central Wellington site and these data do not detail the specific nest-site conditions, such as the extent of nest exposure to the cold, wind, or rain. Additionally, nest abandonment dates are estimates with accuracy determined by the interval between checks. Nevertheless, our result is consistent with anecdotal evidence from other studies on the effects of weather in limiting nest survival of New Zealand Fantails (Blackburn 1966, Powlesland 1982, Miskelly and Sagar 2008).

Our study also shows that nest survival during the earliest stage of nesting, prior to egg-laying, is tenuous. The model including checks per day (the number of observer checks before nest laying/ abandonment expressed as a daily rate) ranked within the top three best models and showed an increased probability of abandonment with more frequent nest checks. Therefore, it is justified for researchers to exercise caution and minimize human presence at nests yet to receive clutches.

Although not investigated in this study, the presence of predators near the nest is also likely to trigger nest-abandonment. BergerTal et al. (2010) tested causes of nest abandonment in Australian Fantails using mounted models of large birds at Grey Fantail nests (Rhipidura albiscapa), a species until recently described as conspecific with the New Zealand Fantail (Schodde et al. 1999, Christidis and Boles 2008). They found nests were abandoned only when models of a known predatory bird were presented. High rates of nest abandonment (47\%) were reported by Munro (2007) for Grey Fantails in a study recording exceptionally high nest predation $(83 \%$ annual average). Furthermore, some abandoned nests are likely to be the result of "cryptic predation" with nests being laid in and subsequently preyed upon between nest-checks, predation therefore going undetected (Maddox and Weatherhead 2006). Other invasive mammalian predators such as mustelids (Mustela spp.) and mice (Mus musculus) are likely to also prey upon fantail nests (Moors 1983) yet their speed or small size may lessen the likelihood of detection by cameras.

Because fantail pairs that abandoned nests did not abandon a second time in the same season (see Fig. A1.2), it is possible that breeding pairs adjust nest placement in a reactive manner where threats are detected. New Zealand Fantails are short lived (average life span of 1 year; Heather et al. 2015) and adults therefore have little chance to refine nesting behavior across multiple breeding seasons, as has been shown for another small passerine (Horie and Takagi 2012). Yet, they have high renesting potential and, as shown for the closely related Grey Fantail (Beckmann et al. 2015, Flegeltaub et al. 2017) and the Australian Bell Miner (Manorina melanophrys; Beckmann and McDonald 2016), adaptive renesting behavior can improve nesting success.

\section{Nest predation}

There was an apparent (near significant) relationship between the chew-card index of localized ship rat abundance and fantail nesting success, because 4 out of 5 nests failed where rat abundance was moderate ( $30-40 \% \mathrm{CCI})$, however, we were unable to model the full range of rat abundance indices in our study. We spent considerable effort trying to locate nests in sites where rat abundance was high, however only two nests were found at sites above $40 \%$ CCI. The lack of nests within such sites might reflect a lower density of breeding pairs of fantails in reserves where rat abundance is high. Results from a study in the North Island report the highest rates of nesting success for nesting fantails (36\%) when rat abundance is low-moderate $(<30 \%$ of tunnels tracked) and $<$ $10 \%$ nesting success where rat abundance was high $(>70 \%$; Sutton et al. 2012). In our study, the density impact function of rats upon nesting fantails followed a proportionate relationship (Norbury et al. 2015) and where rat abundance was highest (e.g., $\geq 30 \%$ CCI), predation on the nest was high, i.e., predation on 4 out of 5 nests. Consequently, an extrapolation of our data suggests survival rates will be low where rat densities are high, i.e., $80 \%$ likelihood of nest predation above $50 \% \mathrm{CCI}$ ) and results from this research and Sutton et al. (2012) show very few fantails raise 
young to the fledgling stage under conditions of high rat abundance.

Although there was no clear relationship between the tracking tunnel index of rat abundance and fantail nesting success, this mostly reflects a difference in scale between our two rodent abundance indices. The nine chew-cards placed around a nest gave a highly localized estimate of ship rat abundance that may be due to just one or a few individual rats in the immediate vicinity of the nest, whereas the tracking tunnel transects provides a more generalized estimate of relative rat abundance at the scale of entire reserves. Tracking tunnel indices have been shown to correspond to actual densities (Brown et al. 1996, Innes et al. 2010b, Christie et al. 2015) but may be less reliable for estimating rats in lower densities (Blackwell et al. 2002) and results may vary with seasons (Christie et al. 2015).

The width of the nest branch and the chew-card index of rodent abundance were the factors that most influenced the probability of nest survival against predation and, according to our results, nests built on thinner branches were afforded some level of protection from predation by rats. Branch width has not previously been shown to limit rat predation on arboreal nests, however nests of Warbling Vireo (Vireo gilvus) located on thinner branches fared better in areas where squirrels (Tamiasciurus douglasii) were the main nest predator (Smith et al. 2005). Whereas the small fantail appears to locate nests on the thinner, outer branches (personal observation), studies of larger species have shown selection for nest placement on more stout branches that are closer to the main stem. This is thought to provide greater support for their nest structures but also for increased concealment as foliage is often more dense closer to the main stem (Zhou et al. 2011).

An evolutionary history of mammalian predation pressure is likely to have shaped nest-site choice in the New Zealand Fantails because these species are closely related to the Australian Grey Fantail (Schodde et al. 1999, Nyári et al. 2009) whose range throughout the southwest pacific supports native, mammalian predators. Additionally, in Zealandia, where mammalian nest predators are removed from the system, avian predation of fantail nests featured more prominently (Table 1), which suggests that mammalian predation on New Zealand Fantail nests may to some extent be compensatory (Newton 1998) with invasive mammals preying upon nests that might otherwise fail to avian predation and vice versa. However, in the New Zealand context, increased avian predation of fantail nests may not necessarily be a sign of enhanced ecological integrity because two of the three avian predations were by an introduced species (Blackbird). Fantail nests were typically located directly under the upper canopy (resulting in a strong correlation between nest height and tree height). This is consistent with avian predation influencing the selection of nest-site because research has shown that increased concealment of nests from above is particularly effective in thwarting avian predators (Brown 1997, Remeš 2005). Nest placement therefore involves trade-offs, such that a nest placed on the thinner-branched, outer reaches of a tree might limit approaches from climbing mammals, yet increases its exposure, making it more vulnerable to avian predators or weather.

Our study shows nest survival of the New Zealand Fantail to be strongly affected by rats. Most reserves in Wellington City are under some form of management to maintain low densities of rats, yet even across this range, fantails suffered significantly heavier losses on nests located at sites where rat abundance was higher. Indeed, the average nesting success of fantails across unfenced reserves in Wellington City was only 44.5\% (2015-2016; Table 1), where average rat tracking was low (6.3\% in 2015-2016; Table A1.1). However, this nesting success rate is comparatively high when compared to success rates of the Grey Fantail in Australia (17\% nesting success; Munro 2007), where native predators cause considerable losses (Flegeltaub et al. 2017). Fantail nesting success in our study was similar to that recorded for North Island Robins where rat abundance was also low (i.e., $\leq 50 \%$ nesting success where tracking rate $<5 \%$ tracking rate; Armstrong et al. 2006) and comparable to nesting success rates of a small, endangered monarch flycatcher in Hawaii, the O'ahu 'Elepaio (Chasiempis sandwichensis ibidis) when numbers of ship rats were markedly reduced (Vanderwerf and Smith 2002). Ship rats continue to exert considerable pressure even when abundance is low, and this has important implications for conservation of less resilient endemic birds.

The Grey Fantail in Australia withstands high rates of nest predation (Munro 2007), and in New Zealand, Blackburn (1966) observed two pairs of fantails fledging a total of 16 young in one breeding season, despite frequent predation and low nesting success (6/ 13 nests successful). The New Zealand Fantail appears to be capable of compensating for moderate levels of nest failure because the birds mature early, i.e., they are able to breed in the first year (Powlesland 1982) and have a high reproductive rate: two life history parameters shown to be important in determining population growth rate potential (Stahl and Oli 2006). However high rates of nest predation by ship rats are likely to limit populations of fantails and other small New Zealand birds that exhibit similar strategies. Populations of small, endemic birds in New Zealand forests, where high densities of invasive rats are the norm (Efford et al. 2006, Ruscoe et al. 2013), are therefore likely to be severely limited and effective conservation of this group, that evolved in the absence of mammalian predators, is likely to require ongoing management of rat populations to low levels.

Responses to this article can be read online at: http://www.ace-eco.org/issues/responses.php/1284

\section{Acknowledgments:}

We thank all the members of the public who helped us locate nests, and to the team at Zealandia for access and support. We are also grateful to John Innes and an anonymous reviewer for comments on earlier drafts. This doctoral research was primarily supported by the Holdsworth Charitable Trust [grant number 80759-2268]. It was also assisted by student awards from the Victoria University of Wellington Centre for Biodiversity and Restoration Ecology [80189-2268], Victoria University of Wellington Faculty for Strategic Research [212746-3619], and a Pukaha Mount Bruce Elwin Welch Memorial grant [2014]. 


\section{LITERATURE CITED}

Amiot, C., W. Ji, and S. D. Hill. 2015. Using plumage and behavioural development to age New Zealand Fantail nestlings. New Zealand Journal of Zoology 42:35-43. http://dx.doi. org/10.1080/03014223.2014.980749

Armstrong, D. P., E. H. Raeburn, R. M. Lewis, and D. Ravine. 2006. Modeling vital rates of a reintroduced New Zealand robin population as a function of predator control. Journal of Wildlife Management 70:1028-1036. http://dx.doi.org/10.2193/0022-541X (2006)70[1028:MVROAR]2.0.CO;2

Atkinson, I. A. E. 1985. The spread of commensal species of Rattus to oceanic islands and their effects on island avifaunas. Pages 35-81 in P. J. Moors, editor. Conservation of island birds. Technical Publication No. 3 edition, International Council for Bird Preservation, Cambridge, UK.

Barton, K. 2016. MuMIn: multi-model inference R package (Version 1.15.6). Vienna, Austria. [online] URL: http://CRAN. R-project.org/package $=$ MuMIn/

Bates, D., M. Mächler, B. M. Bolker, and S. C. Walker. 2015. Fitting linear mixed-effects models using lme4. Journal of Statistical Software 67:1-48. http://dx.doi.org/10.18637/jss.v067. i01

Beckmann, C., P. A. Biro, and K. Martin. 2015. Hierarchical analysis of avian re-nesting behavior: mean, across-individual, and intra-individual responses. Behavioral Ecology and Sociobiology 69:1631-1638. http://dx.doi.org/10.1007/s00265-015-1974-1

Beckmann, C., and P. G. McDonald. 2016. Placement of re-nests following predation: are birds managing risk? Emu 116:9-13. http://dx.doi.org/10.1071/MU15064

Berger-Tal, R., O. Berger-Tal, and K. Munro. 2010. Nest desertion by Grey Fantails during nest building in response to perceived predation risk. Journal of Field Ornithology 81:151-154. http://dx. doi.org/10.1111/j.1557-9263.2010.00272.x

Blackburn, A. 1966. Some further observations on the nesting of the North Island Fantail. Notornis 13:189-196.

Blackburn, T. M., P. Cassey, R. P. Duncan, K. L. Evans, and K. J. Gaston. 2004. Avian extinction and mammalian introductions on Oceanic Islands. Science 305:1955-1958. http://dx.doi. org/10.1126/science. 1101617

Blackwell, G. L., M. A. Potter, and J. A. McLennan. 2002. Rodent density indices from tracking tunnels, snap-traps and fenn traps: do they tell the same story? New Zealand Journal of Ecology 26:43-51.

Brown, K. P. 1997. Predation at nests of two New Zealand endemic passerines; implications for bird community restoration. Pacific Conservation Biology 3:91-98. http://dx.doi.org/10.1071/ PC970091

Brown, K. P., H. Moller, J. Innes, and N. Alterio. 1996. Calibration of tunnel tracking rates to estimate relative abundance of ship rats (Rattus rattus) and mice (Mus musculus) in a New Zealand forest. New Zealand Journal of Ecology 20:271-275.

Brown, K. P., H. Moller, J. Innes, and P. Jansen. 1998. Identifying predators at nests of small birds in a New Zealand forest. Ibis 140:274-279. http://dx.doi.org/10.1111/j.1474-919X.1998.tb04389.
Burnham, K. P., and D. R. Anderson. 2002. Model selection and multimodel inference: a practical information-theoretic approach. Springer Science \& Business Media, New York, New York, USA.

Christidis, L., and W. E. Boles. 2008. Systematics and taxonomy of Australian birds. CSIRO, Collingwood, Australia.

Christie, J. E., D. I. MacKenzie, T. C. Greene, and J. L. Sim. 2015. Using passive detection devices to monitor occupancy of ship rats (Rattus rattus) in New Zealand temperate rainforest. New Zealand Journal of Ecology 39:79-86.

Cohen, J. E., S. L. Pimm, P. Yodzis, and J. Saldana. 1993. Body sizes of animal predators and animal prey in food webs. Journal of Animal Ecology 62:67-78. http://dx.doi.org/10.2307/5483

Colombelli-Négrel, D., and S. Kleindorfer. 2009. Nest height, nest concealment, and predator type predict nest predation in superb fairy-wrens (Malurus cyaneus). Ecological Research 24:921-928. http://dx.doi.org/10.1007/s11284-008-0569-y

Conrey, R. Y., S. K. Skagen, A. A. Y. Adams, and A. O. Panjabi. 2016. Extremes of heat, drought and precipitation depress reproductive performance in shortgrass prairie passerines. Ibis 158:614-629. http://dx.doi.org/10.1111/ibi.12373

Courchamp, F., J.-L. Chapuis, and M. Pascal. 2003. Mammal invaders on islands: impact, control and control impact. Biological Reviews 78:347-383. http://dx.doi.org/10.1017/ S1464793102006061

Department of Conservation. 2014. The Foliar browse index field manual. An update of a method for monitoring possum (Trichosurus vulpecula) damage to forest communities. Department of Conservation, Christchurch, New Zealand. [online] URL: https://nvs.landcareresearch.co.nz/Content/ FOLIAR_BROWSE_INDEX.pdf

Dinsmore, S. J., and J. J. Dinsmore. 2007. Modeling avian nest survival in program mark. Studies in Avian Biology 34:73-83.

Doherty, T. S., A. S. Glen, D. G. Nimmo, E. G. Ritchie, and C. R. Dickman. 2016. Invasive predators and global biodiversity loss. Proceedings of the National Academy of Sciences of the United States of America 113:11261-11265. http://dx.doi. org/10.1073/pnas. 1602480113

Duron, Q., A. B. Shiels, and E. Vidal. 2017. Control of invasive rats on islands and priorities for future action. Conservation Biology 31:761-771. http://dx.doi.org/10.1111/cobi.12885

Efford, M. G., B. M. Fitzgerald, B. J. Karl, and P. H. Berben. 2006. Population dynamics of the ship rat Rattus rattus L. in the Orongorongo Valley, New Zealand. New Zealand Journal of Zoology 33:273-297. http://dx.doi.org/10.1080/03014223.2006.9518457

Elliott, G. P., P. J. Dilks, and C. F. J. O'Donnell. 1996. Nest site selection by Mohua and Yellow-crowned Parakeets in beech forest in Fiordland, New Zealand. New Zealand Journal of Zoology 23:267-278. http://dx.doi.org/10.1080/03014223.1996.9518085

Elliott, G. P., J. Kemp, and J. C. Russell. 2018. Estimating population growth rates from tracking tunnels. New Zealand Journal of Ecology 42(2):269-272. http://dx.doi.org/10.20417/ nzjecol.42.19

Empson, R., and D. Fastier. 2013. Translocations of North Island Tomtits (Petroica macrocephala toitoi) and North Island Robins 
(P. longipes) to Zealandia-Karori Sanctuary, an urban sanctuary. What have we learned? Notornis 60:63-69.

Flegeltaub, M., P. A. Biro, and C. Beckmann. 2017. Avian nest abandonment prior to laying-a strategy to minimize predation risk? Journal of Ornithology 158:1091-1098. http://dx.doi. org/10.1007/s10336-017-1470-7

Foster, S., C. King, B. Patty, and S. Miller. 2011. Tree-climbing capabilities of Norway and ship rats. New Zealand Journal of Zoology 38:285-296. http://dx.doi.org/10.1080/03014223.2011.599400

Gabites, I. 1993. Wellington's living cloak. Victoria University Press, Wellington, New Zealand.

Gillies, C. A., M. R. Leach, N. B. Coad, S. W. Theobald, J. Campbell, T. Herbert, P. J. Graham, and R. J. Pierce. 2003. Six years of intensive pest mammal control at Trounson Kauri Park, a Department of Conservation "mainland island", June 1996July 2002. New Zealand Journal of Zoology 30:399-420. http://dx. doi.org/10.1080/03014223.2003.9518349

Gillies, C., and D. Williams. 2013. DOC tracking tunnel guide v2.5.2: using tracking tunnels to monitor rodents and mustelids. Department of Conversation, Science \& Capability Group, Hamilton, New Zealand. [online] URL: http://www.doc.govt.nz/ Documents/science-and-technical/inventory-monitoring/im-toolboxanimal-pests-using-tracking-tunnels-to-monitor-rodents-and-mustelids. pdf

Griffiths, J. W., and M. C. Barron. 2016. Spatiotemporal changes in relative rat (Rattus rattus) abundance following large-scale pest control. New Zealand Journal of Ecology 40:371-380. http://dx. doi.org/10.20417/nzjecol.40.33

Heather, B. D., H. A. Robertson, and D. Onley. 2015. The field guide to the birds of New Zealand. Viking-Penguin Books, Auckland, New Zealand.

Holdaway, R. N., T. H. Worthy, and A. J. D. Tennyson. 2001. A working list of breeding bird species of the New Zealand region at first human contact. New Zealand Journal of Zoology 28:119-187. http://dx.doi.org/10.1080/03014223.2001.9518262

Horie, S., and M. Takagi. 2012. Nest positioning by male Daito White-eyes Zosterops japonicus daitoensis improves with age to reduce nest predation risk. Ibis 154:285-295. http://dx.doi. org/10.1111/j.1474-919X.2011.01204.X

Innes, J., R. Hay, I. Flux, P. Bradfield, H. Speed, and P. Jansen. 1999. Successful recovery of North Island Kokako Callaeas cinerea wilsoni populations, by adaptive management. Biological Conservation 87:201-214. http://dx.doi.org/10.1016/S0006-3207 (98)00053-6

Innes, J., D. Kelly, J. Overton, and C. Gillies. 2010a. Predation and other factors currently limiting New Zealand forest birds. New Zealand Journal of Ecology 34:86-114.

Innes, J., C. M. King, L. Bridgman, N. Fitzgerald, G. Arnold, and N. Cox. 2010b. Effect of grazing on ship rat density in forest fragments of lowland Waikato, New Zealand. New Zealand Journal of Ecology 34:227-232.

Innes, J., B. Warburton, D. Williams, H. Speed, and P. Bradfield. 1995. Large-scale poisoning of ship rats (Rattus rattus) in indigenous forests of the North-Island, New-Zealand. New Zealand Journal of Ecology 19:5-17.

Johnson, T. H., and A. J. Stattersfield. 1990. A global review of island endemic birds. Ibis 132:167-180. http://dx.doi.org/10.1111/ j.1474-919X.1990.tb01036.x

King, C. M. 2005. The handbook of New Zealand mammals. Second edition. Oxford University Press, Melbourne, Australia.

Maddox, J. D., and P. J. Weatherhead. 2006. Nests without eggs: abandonment or cryptic predation? Auk 123:135-140. http://dx doi.org/10.1642/0004-8038(2006)123[0135:NWEAOC]2.0.CO;2

Martin, T. E. 1993. Nest predation and nest sites - new perspectives on old patterns. Bioscience 43:523-532. http://dx.doi. org/10.2307/1311947

Massaro, M., A. Starling-Windhof, J. V. Briskie, and T. E. Martin. 2008. Introduced mammalian predators induce behavioural changes in parental care in an endemic New Zealand bird. PLoS ONE 3:e2331. http://dx.doi.org/10.1371/journal.pone.0002331

Mayfield, H. F. 1975. Suggestions for calculating nest success. Wilson Bulletin 87:456-466.

Miskelly, C. M., and P. M. Sagar. 2008. Establishment and local extinction of fantails (Rhipidura fuliginosa) on the Snares Islands, New Zealand. Notornis 55:170-171.

Moors, P. J. 1983. Predation by mustelids and rodents on the eggs and chicks of native and introduced birds in Kowhai Bush, NewZealand. Ibis 125:137-154. http://dx.doi.org/10.1111/j.1474-919X.1983. tb03095.x

Mudge, D. 2002. Silence of the fantails. New Zealand Geographic 55:71-85.

Munro, K. 2007. Breeding behaviour and ecology of the Grey Fantail (Rhipidura albiscapa). Australian Journal of Zoology 55:257-265. http://dx.doi.org/10.1071/ZO07025

Newton, I. 1998. Population limitation in birds. Academic, San Diego, California, USA.

Norbury, G. L., R. P. Pech, A. E. Byrom, and J. Innes. 2015. Density-impact functions for terrestrial vertebrate pests and indigenous biota: guidelines for conservation managers. Biological Conservation 191:409-420. http://dx.doi.org/10.1016/j. biocon.2015.07.031

Nyári, A. S., B. W. Benz, K. A. Jønsson, J. Fjeldså, and R. G. Moyle. 2009. Phylogenetic relationships of fantails (Aves: Rhipiduridae). Zoologica Scripta 38:553-561. http://dx.doi. org/10.1111/j.1463-6409.2009.00397.x

Payton, M. E., M. H. Greenstone, and N. Schenker. 2003. Overlapping confidence intervals or standard error intervals: What do they mean in terms of statistical significance? Journal of Insect Science 3:34. http://dx.doi.org/10.1093/jis/3.1.34

Powlesland, M. H. 1982. A breeding study of the South Island Fantail Rhipidura fuliginosa fuliginosa. Notornis 29:181-195.

Remeš, V. 2005. Birds and rodents destroy different nests: a study of Blackcap Sylvia atricapilla using the removal of nest concealment. Ibis 147:213-216. http://dx.doi.org/10.1111/ j.1474-919X.2004.00339.x 
Richardson, T. W., T. Gardali, and S. H. Jenkins. 2009. Review and meta-analysis of camera effects on avian nest success. Journal of Wildlife Management 73:287-293. http://dx.doi.org/10.2193/2007-566

Robertson, H. A., J. R. Hay, E. K. Saul, and G. V. McCormack. 1994. Recovery of the Kakerori: an endangered forest bird of the Cook Islands. Conservation Biology 8:1078-1086. http://dx.doi. org/10.1046/j.1523-1739.1994.08041078.x

Rotella, J. 2015. Nest survival models. Chapter 17 in E. G. Cooch and G. C. White, editors. Program MARK - a gentle introduction. Program MARK, USA. [online] URL: http://www.phidot.org/ software/mark/docs/book/pdf/chap17.pdf

Ruscoe, W. A., D. S. L. Ramsey, R. P. Pech, P. J. Sweetapple, I. Yockney, M. C. Barron, M. Perry, G. Nugent, R. Carran, R. Warne, C. Brausch, and R. P. Duncan. 2011. Unexpected consequences of control: competitive vs. predator release in a four-species assemblage of invasive mammals. Ecology Letters 14:1035-1042. http://dx.doi.org/10.1111/j.1461-0248.2011.01673. $\mathrm{x}$

Ruscoe, W. A., P. J. Sweetapple, M. Perry, and R. P. Duncan. 2013. Effects of spatially extensive control of invasive rats on abundance of native invertebrates in mainland New Zealand forests. Conservation Biology 27:74-82. http://dx.doi.org/10.1111/ j.1523-1739.2012.01932.x

Schodde, R., I. J. Mason, R. Schodde, and I. J. Mason. 1999. The directory of Australian birds. A taxonomic and zoogeographic atlas of the biodiversity of birds in Australia and its territories. Passerines. CSIRO, Melbourne, Australia.

Shiels, A. B., W. C. Pitt, R. T. Sugihara, and G. W. Witmer. 2014. Biology and impacts of Pacific Island invasive species. 11. Rattus rattus, the Black Rat (Rodentia: Muridae). Pacific Science 68:145-184. http://dx.doi.org/10.2984/68.2.1

Smith, J. I., M. D. Reynolds, and G. LeBuhn. 2005. Warbling Vireo reproductive success and nest-site characteristics in the northern Sierra Nevada, California. Journal of Field Ornithology 76:383-389. http://dx.doi.org/10.1648/0273-8570-76.4.383

Stahl, J. T., and M. K. Oli. 2006. Relative importance of avian life-history variables to population growth rate. Ecological Modelling 198:23-39. http://dx.doi.org/10.1016/j.ecolmodel.2006.04.001

Stirnemann, R. L., M. A. Potter, D. Butler, and E. O. Minot. 2015. Compounding effects of habitat fragmentation and predation on bird nests. Austral Ecology 40:974-981. http://dx.doi.org/10.1111/ aec. 12282

Sutton, N., J. Guillotel, and R. Potae. 2012. Tongariro Forest Kiwi Sanctuary annual report, July 2011 - June 2012. Department of Conversation, Wellington, New Zealand. [online] URL: http:// www.doc.govt.nz/Documents/conservation/native-animals/birds/ tfks-annual-report-2011-12.pdf
Sweetapple, P., and G. Nugent. 2011. Chew-track-cards: a multiple-species small mammal detection device. New Zealand Journal of Ecology 35:153-162.

Sweetapple, P. J., and G. Nugent. 2007. Ship rat demography and diet following possum control in a mixed podocarp-hardwood forest. New Zealand Journal of Ecology 31:186-201.

Towns, D. R., I. A. E. Atkinson, and C. H. Daugherty. 2006. Have the harmful effects of introduced rats on islands been exaggerated? Biological Invasions 8:863-891. http://dx.doi. org/10.1007/s10530-005-0421-Z

van Heezik, Y., K. Ludwig, S. Whitwell, and I. G. McLean. 2008. Nest survival of birds in an urban environment in New Zealand. New Zealand Journal of Ecology 32:155-165.

Vanderwerf, E. A. 2012. Evolution of nesting height in an endangered Hawaiian forest bird in response to a non-native predator. Conservation Biology 26:905-911. http://dx.doi. org/10.1111/j.1523-1739.2012.01877.x

Vanderwerf, E. A., and D. G. Smith. 2002. Effects of alien rodent control on demography of the O'ahu 'Elepaio, an endangered Hawaiian forest bird. Pacific Conservation Biology 8:73-81. http:// dx.doi.org/10.1071/PC020073

White, G. C., and K. P. Burnham. 1999. Program MARK: survival estimation from populations of marked animals. Bird Study 46: S120-S139. http://dx.doi.org/10.1080/00063659909477239

Worthy, T. H., and R. N. Holdaway. 2002. The lost world of the Moa: prehistoric life of New Zealand. Indiana University Press, Bloomington, Indiana, USA.

Zhou, D., C. Zhou, X. Kong, and W. Deng. 2011. Nest-site selection and nesting success of Grey-backed Thrushes in northeast China. Wilson Journal of Ornithology 123:492-501. http://dx.doi.org/10.1676/10-110.1
Editor-in-Chief: Keith A.Hobson Subject Editor: Alexander L.Bond
Sponsored by the Society of Canadian Ornithologists and Bird Studies Canada Parrainée par la Société des ornithologistes $d u$ Canada et Etudes d'oiseaux Canada

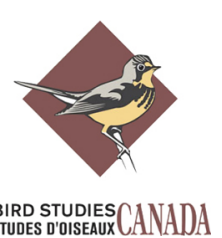


Appendix 1. Additional information to support the online article is available in this appendix, including: a table with rat abundance estimates and New Zealand Fantail (Rhipidura fuliginosa placabilis, North Island subspecies) nest success for the Wellington sites (Table A1.1); a table showing the multimodel assessment of the influence of time-dependent factors on survival of fantail nests (Table A1.2); a figure showing the location of the study site in New Zealand, plus the locations of nests in Wellington City (Fig. A1.1); and a figure where individual fates for all nests found between 2014 and 2016 are plotted across the nesting season (Fig. A1.2).

Table A1.1. Nesting outcomes by site for fantails in Wellington City.

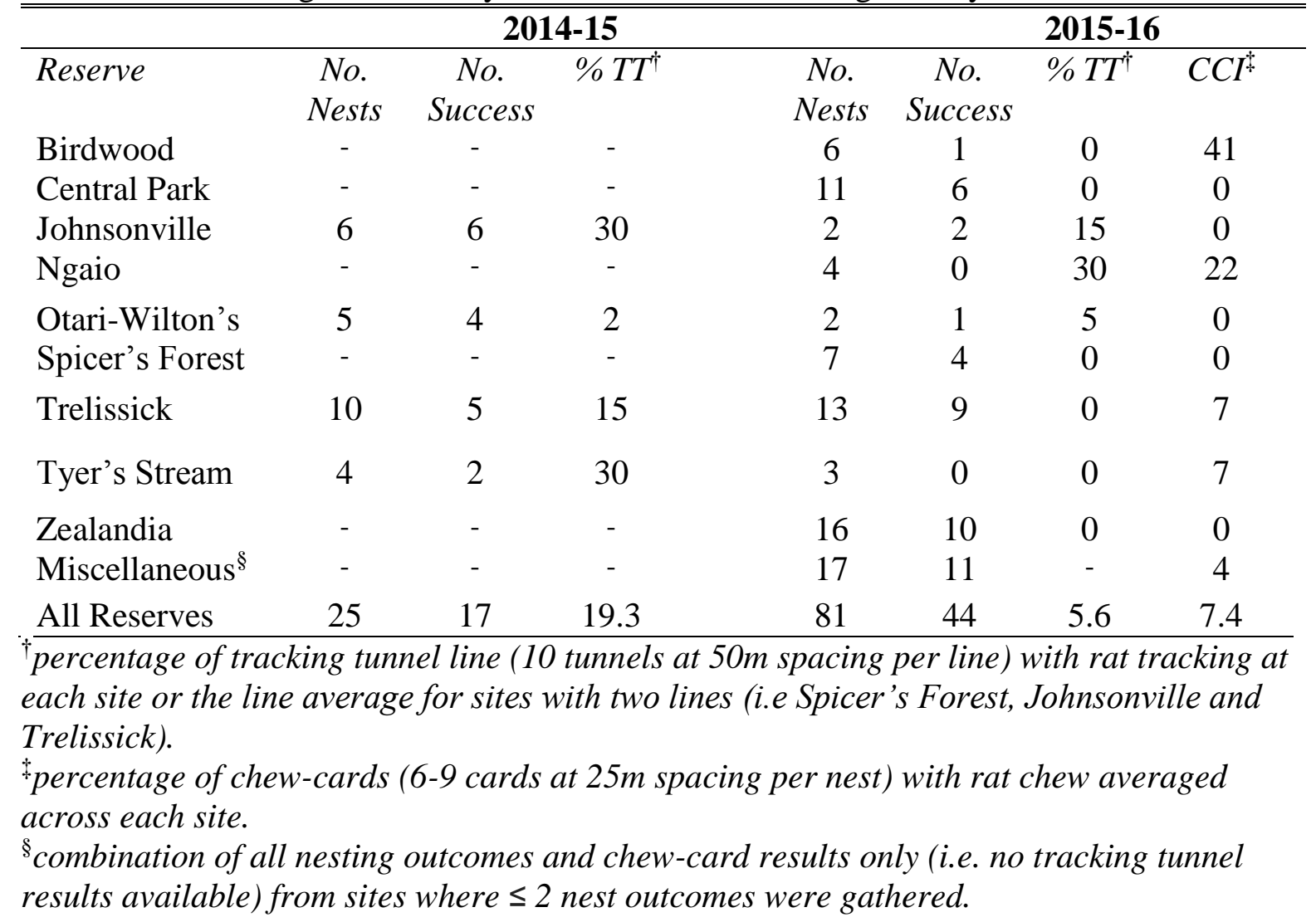


Table A1.2. Multimodel assessment of the influence of time-dependent factors on survival of fantail nests as calculated in program Mark $(n=61)$. Factors include: nest phase (chick/nestling), nest age, linear time (by season day) and season stage (early, middle or late stage). All models include a constant intercept term.

\begin{tabular}{ccccccccc}
\hline \hline constant & $\begin{array}{c}\text { nest } \\
\text { phase }\end{array}$ & $\begin{array}{c}\text { nest } \\
\text { age }\end{array}$ & $\begin{array}{c}\text { linear } \\
\text { time }\end{array}$ & $\begin{array}{c}\text { season } \\
\text { stage }\end{array}$ & $\mathrm{K}^{\dagger}$ & $\operatorname{logLik}$ & $\begin{array}{c}\Delta^{\S} \\
\text { AICc }\end{array}$ & $W_{i}{ }^{\dagger}$ \\
\hline $\mathrm{X}$ & & & & & 1 & 1.00 & 0.00 & 0.36 \\
$\mathrm{X}$ & $\mathrm{X}$ & & & & 2 & 0.45 & 1.58 & 0.17 \\
$\mathrm{X}$ & & & $\mathrm{X}$ & & 2 & 0.38 & 1.95 & 0.14 \\
$\mathrm{X}$ & & $\mathrm{X}$ & & & 2 & 0.37 & 1.95 & 0.13 \\
$\mathrm{X}$ & & & & $\mathrm{X}$ & 2 & 0.24 & 2.88 & 0.09 \\
$\mathrm{X}$ & $\mathrm{X}$ & & $\mathrm{X}$ & & 3 & 0.18 & 3.50 & 0.06 \\
$\mathrm{X}$ & & $\mathrm{X}$ & $\mathrm{X}$ & & 3 & 0.14 & 3.96 & 0.05 \\
\hline
\end{tabular}

number of parameters.

the maximized log-likelihood function.

${ }^{\$}$ difference in AICc value for parameter relative to the top parameter.

the AICc weight for the model in the set. 


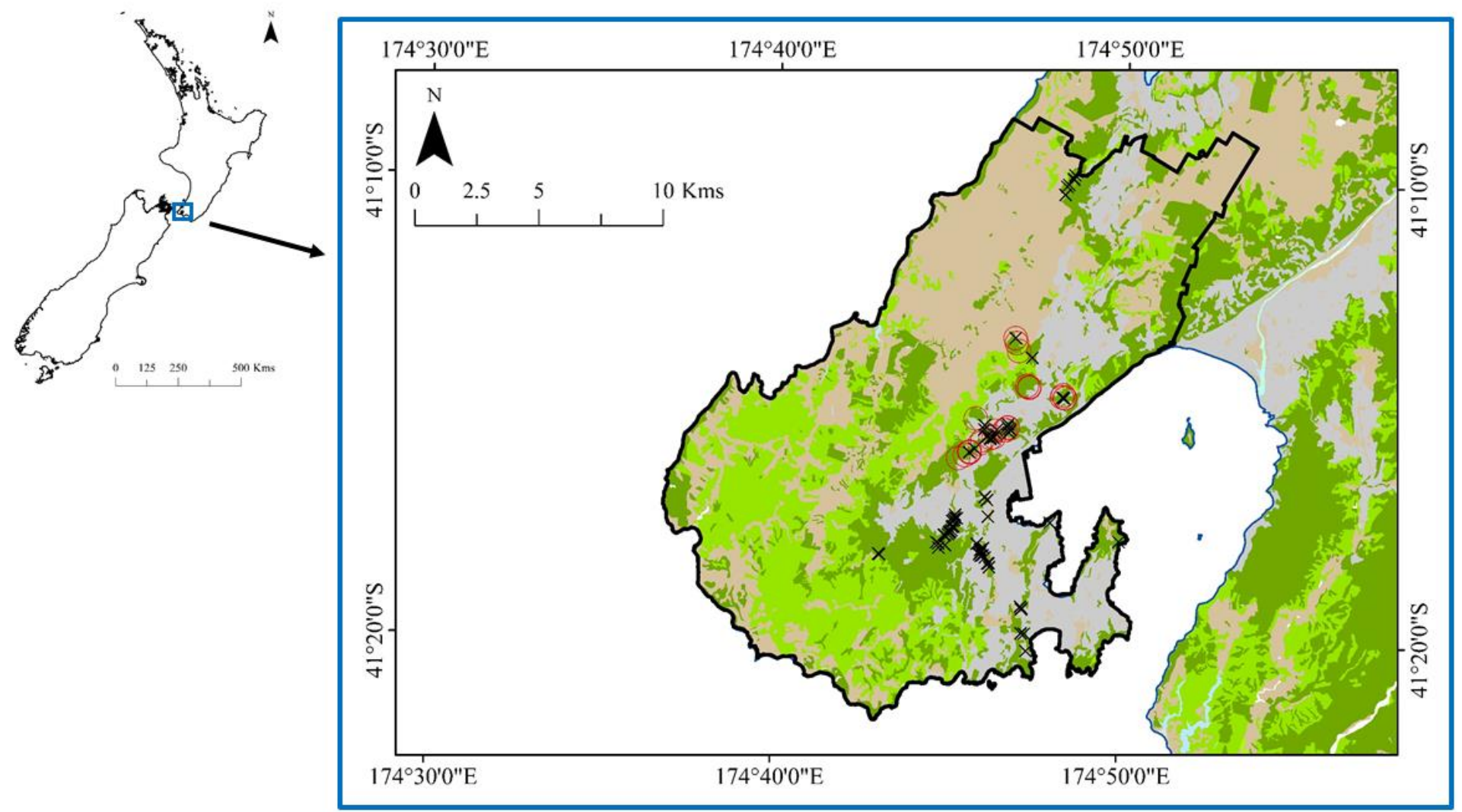

Fig. A1.1. Location of study. Left map: New Zealand showing location of Wellington City; right map: fantail nest locations for 2014-15 (red circles) and 2015-16 (black crosses). Colour key: green = forest (dark green = native $/$ exotic mixed, light green $=$ exotic forest); grey = buildings and roading; brown = grassland $/$ pasture; black outline $=$ the Wellington City Council management boundary. 


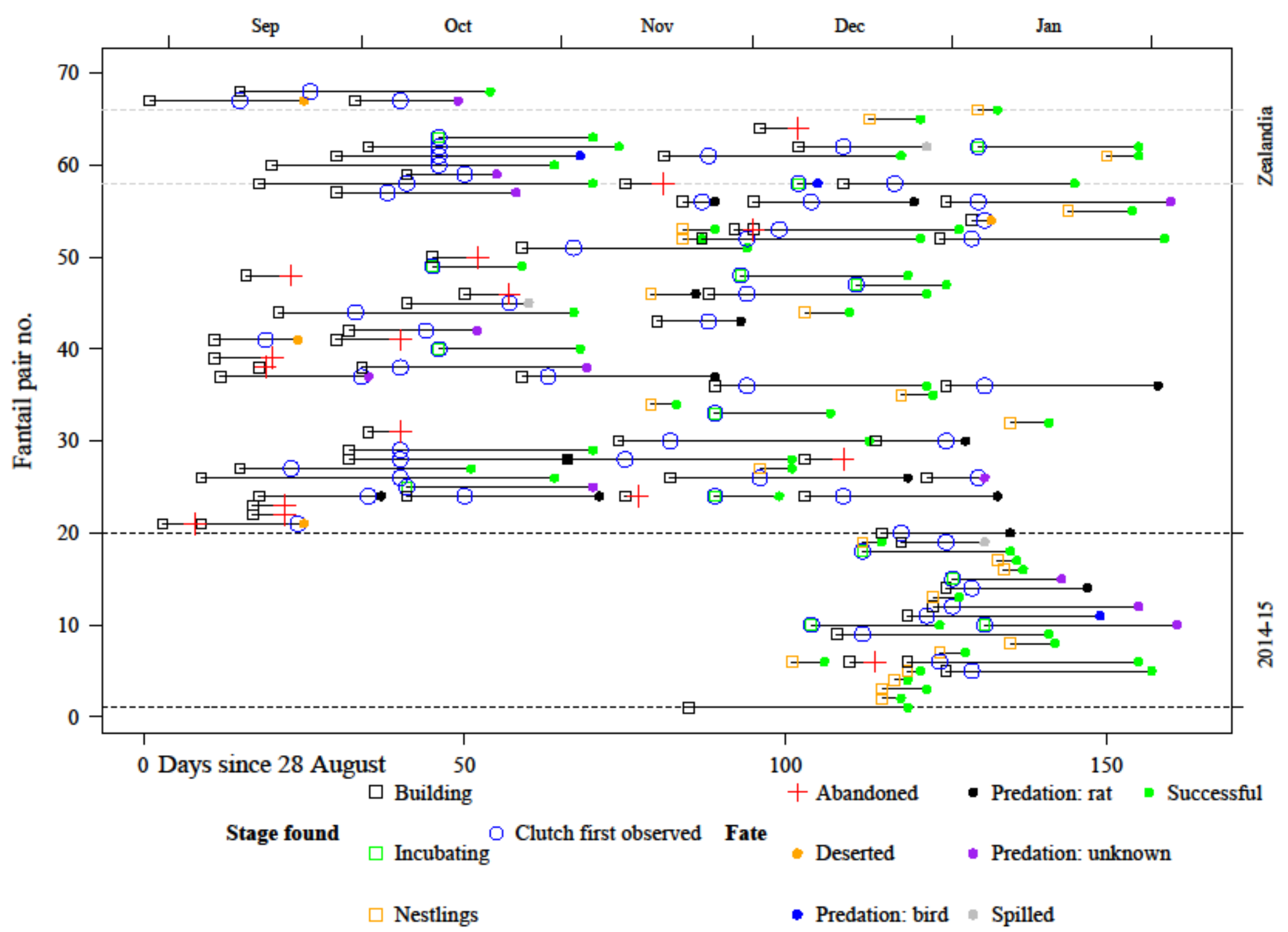


Fig. A1.2. Individual nest fates plotted across the season for the 68 fantail breeding pairs monitored in Wellington City reserves from 20142016. Horizontal continuous lines spaced along a single row represent nest attempts of a pair of fantails from a single breeding season. Dashed horizontal lines delineate breeding seasons (2014-15 and 2015-16) as well as nests from the second breeding season located in Zealandia, a fenced eco-sanctuary where invasive mammals, except mice, have been removed. 'Stage found' describes the stage of the nest when first discovered advancing from Building (parents were seen constructing the nest) to Incubating (nest had eggs) to Nestlings (nest had hatched chicks). 'Clutch first observed' describes the day the nest was initially observed with eggs (i.e. this observation was not possible for nests discovered at 'Nestling' stage). 'Fate' describes the outcome of the nest. 